\title{
LACTATE DEHYDROGENASE IN SYNOVIAL FLUID DIAGNOSTIC EVALUATION OF TOTAL ACTIVITY AND ISOENZYME PATTERNS
}

\author{
BY \\ E. M. VEYS AND R. J. WIEME \\ From the Department of Physical Medicine and Orthopaedic Surgery and the Laboratory for Protein Chemistry, \\ Department of Internal Medicine, Academic Hospital, University of Ghent, Belgium
}

The work of Ropes and Bauer (1953) has focused attention on the analysis of synovial fluid in the differential diagnosis of joint effusion. White blood cell total and differential counts, glucose assay, and mucin precipitation tests have thus all been applied to the distinction of non-inflammatory, mild inflammatory, severe inflammatory, and infectious effusions. These analyses do not, however, indicate the true origin of the effusion, and we have carried out this investigation to find out whether differential assay of lactate dehydrogenase (LDH) isoenzymes could yield more specific information.

It is known that the percentage of polymorphonuclear cells (PMN) and of lymphocytes is different in non-inflammatory, inflammatory, and infectious effusions. Recent studies (Dioguardi, Agostoni, Fiorelli, and Lomanto, 1963; Bottomley, Locke, and Ingram, 1966; Hule, 1967) indicate that polymorphonuclear cells and lymphocytes have different LDH isoenzyme patterns. One may thus expect to find LDH shifts in parallel with the type of the cellular material. It could also be of interest to look for any enzyme contribution originating in the lining walls of the synovia.

Vesell, Osterland, Bearn, and Kunkel (1962) and especially Cohen (1964), who studied the LDH activity of synovial fluid in rheumatic disease states, reported that total synovial fluid LDH was raised in patients with inflammatory articular disease, and found marked rises of LDH5 in total synovial fluids of rheumatoid, gouty, and infected joints. They only found a minimal increase of LDH5 in fluids from cases of degenerative joint disease. Although these observations suggest that this type of analysis will be of little diagnostic value, one must remember that Vesell and others (1962) studied only a limited number of cases, including several of ill-defined aetiology. Cohen (1964) used LDH isoenzyme differentiation only as a complement to other enzyme studies; he confined himself to a visual interpretation of the $\mathbf{L D H}$ patterns in a relatively small number of cases.

We therefore felt that interesting results might be obtained by applying a quantitative technique of LDH differentiation to a large number of cases of well-established aetiology.

We have also determined LDH isoenzyme patterns separately on cell-free fluid and on cellular material after ultrasonic disintegration.

\section{Methods}

Synovial fluids were aspirated with sterile precautions from different joints (knee, elbow, hip, ankle) without using local anesthetics. In supplement to the analyses mentioned, the fluids were also submitted to bacteriological culture and to differential count of the white blood cells.

Before the determination of total LDH activity and analysis of the LDH patterns, a constant amount of the synovial fluid $(10 \mathrm{ml}$.) was centrifuged at $50,000 \mathrm{G}$. and $10^{\circ} \mathrm{C}$. temperature for $30 \mathrm{~min}$. In this way a clear cell-free supernatant and a cellular sediment were obtained. The supernatant was used as such. The sediment was washed three times with saline and finally resuspended in exactly $5 \mathrm{ml}$. saline. This suspension was submitted to ultrasonic disintegration (MSE, type 5.65 ; power set at $1 \cdot 0-1 \cdot 5 \mathrm{amp}$.) for $5 \mathrm{~min}$, with cooling in an ice bath.

Total LDH activity and LDH isoenzyme percentages were then determined on both fractions, designated supernatant and cellular material respectively.

Total LDH Activity.-This was determined by a spectrophotometric technique using the pyruvate to lactate conversion. The reaction mixture contained sodium veronal buffer $(1.65 \mathrm{ml} ., \mathrm{pH} 8 \cdot 4$, ionic strength $0.05)$, sample $(0.2 \mathrm{ml}$ ), reduced diphosphopyridine nucleotide ( $\mathrm{NADH}_{2}, 0.1 \mathrm{ml}$. of a $5 \times 10^{-3} \mathrm{~mol}$. solution).

The reaction was started by adding pyruvate $(0.05 \mathrm{ml}$., $6 \times 10^{-2} \mathrm{~mol}$.). The kinetics were followed at $37^{\circ} \mathrm{C}$. in a Zeiss spectrophotometer PMQ II, wavelength 340 $\mathrm{m} \mu$. Results are reported in international units/millilitre (i.u./ml.). 
LDH Isoenzymes. - These were separated by the agar gel electrophoresis procedure of Wieme $(1959,1965)$. The LDH fractions were visualized by the sandwich technique of Wieme, van Sande, Karcher, Lowenthal, and van der Helm (1962) using a tetrazolium salt as described by van der Helm (1961). After the detection of enzymatic zones the double layer was fixed in 2 per cent. acetic acid in 70 vol. per cent. ethanol for $2 \mathrm{hrs}$ and then dried overnight under filter paper at $37^{\circ} \mathrm{C}$. The film was finally scanned at $540 \mathrm{~m} \mu$. in a Vitatron spectrophotometer (type U.R. 100). Records were effected in the logarithmic mode on the companion recorder. Percentages of the $\mathrm{LDH}$ fractions were calculated from the automatic integrator data.

\section{Material}

86 synovial fluids were analysed by these methods. The diagnoses are presented in Table $I$.
TABLE I

DISTRIBUTION OF CASES ACCORDING TO AETIOLOGY

\begin{tabular}{l|c|c}
\hline \multicolumn{1}{c|}{ Diagnosis } & No. of Cases & No. of Fluids \\
\hline Rheumatoid arthritis & 51 & 56 \\
Juvenile rheumatoid arthritis & 4 & 6 \\
Degenerative arthritis & 4 & 4 \\
Traumatic joint effusion & 8 & 8 \\
Infectious arthritis & 2 & 2 \\
Gouty arthritis & 2 & 2 \\
Ankylosing spondylitis & 1 & 1 \\
Arthritis of unknown origin & 6 & 7 \\
\hline Total & 78 & 86 \\
\hline
\end{tabular}

\section{Results}

The results were summarized by number of cases, mean values, standard deviation, standard error, and range. The frequency distribution of the results obtained for the total $\mathrm{LDH}$ and the WBC counts are of the log normal type. The standard deviations and standard errors which are given rather as complementary data, should thus be

SYNOVIAL FLUIDS OF PATIENTS W'्6TH

\begin{tabular}{|c|c|c|c|c|c|c|c|c|c|c|c|}
\hline & & & & & & \multicolumn{6}{|c|}{ Supernatant } \\
\hline \multicolumn{6}{|c|}{ Observations } & $\begin{array}{c}\text { Total LDH } \\
\text { Activity } \\
\text { (i.u./ml.) }\end{array}$ & \multicolumn{5}{|c|}{ Percentages } \\
\hline $\begin{array}{l}\text { Mean ... } \\
\text { Standard Deviation } \\
\text { Standard Error }\end{array}$ & $\cdots$ & $\begin{array}{l}\cdots \\
\cdots \\
\cdots\end{array}$ & $\begin{array}{l}\cdots \\
\cdots \\
\cdots\end{array}$ & $\begin{array}{l}\cdots \\
\cdots \\
\cdots\end{array}$ & $\begin{array}{l}\cdots \\
\cdots \\
\cdots\end{array}$ & $\begin{array}{l}2 \cdot 32 \\
2 \cdot 05 \\
0 \cdot 71\end{array}$ & $\begin{array}{r}14 \cdot 3 \\
6 \cdot 1 \\
1 \cdot 0\end{array}$ & $\begin{array}{r}17 \cdot 3 \\
3 \cdot 1 \\
0 \cdot 5\end{array}$ & $\begin{array}{r}20 \cdot 1 \\
4 \cdot 6 \\
0 \cdot 6\end{array}$ & $\begin{array}{r}19 \cdot 6 \\
3 \cdot 1 \\
0 \cdot 4\end{array}$ & \\
\hline $\begin{array}{l}\text { Range: Min. } \\
\text { Max. }\end{array}$ & $\begin{array}{l}\ldots \\
\ldots\end{array}$ & . & $\begin{array}{l}\cdots \\
\cdots\end{array}$ & $\begin{array}{l}\ldots \\
\text {. }\end{array}$ & $\begin{array}{l}\text {. } \\
\text {. }\end{array}$ & $\begin{array}{r}0 \cdot 31 \\
11 \cdot 52\end{array}$ & $\begin{array}{r}8 \cdot 5 \\
34 \cdot 5\end{array}$ & $\begin{array}{l}11 \cdot 5 \\
24 \cdot 0\end{array}$ & $\begin{array}{r}8 \cdot 6 \\
45 \cdot 5\end{array}$ & $\begin{array}{r}8 \cdot 2 \\
26 \cdot 6\end{array}$ & $\begin{array}{r}8 \cdot 4 \\
41 \cdot 8\end{array}$ \\
\hline
\end{tabular}

SYNOVIAL FLUIDS OF PATIENTS

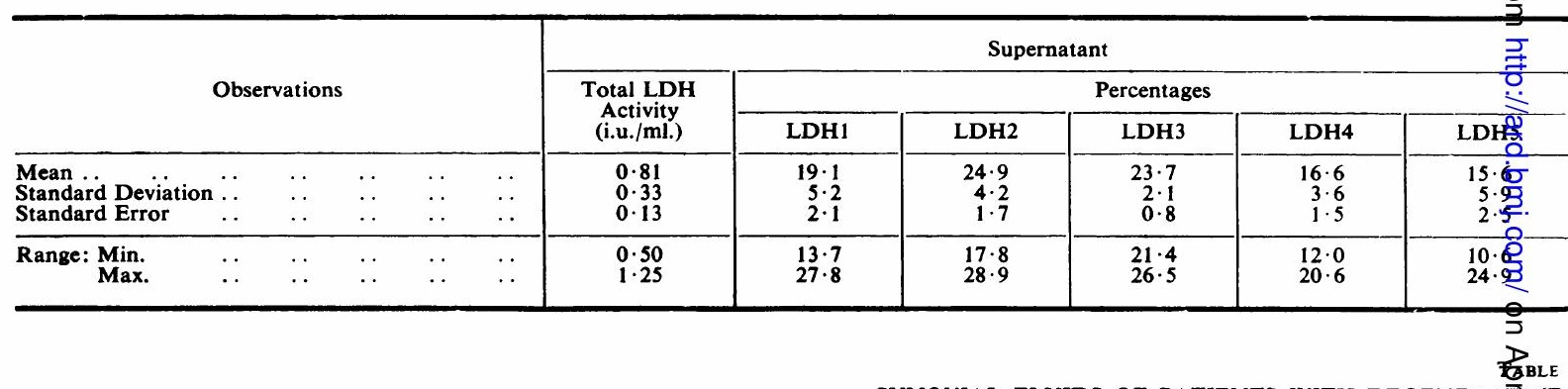

SYNOVIAL FLUIDS OF PATIENTS WITH DEGENERA至VE

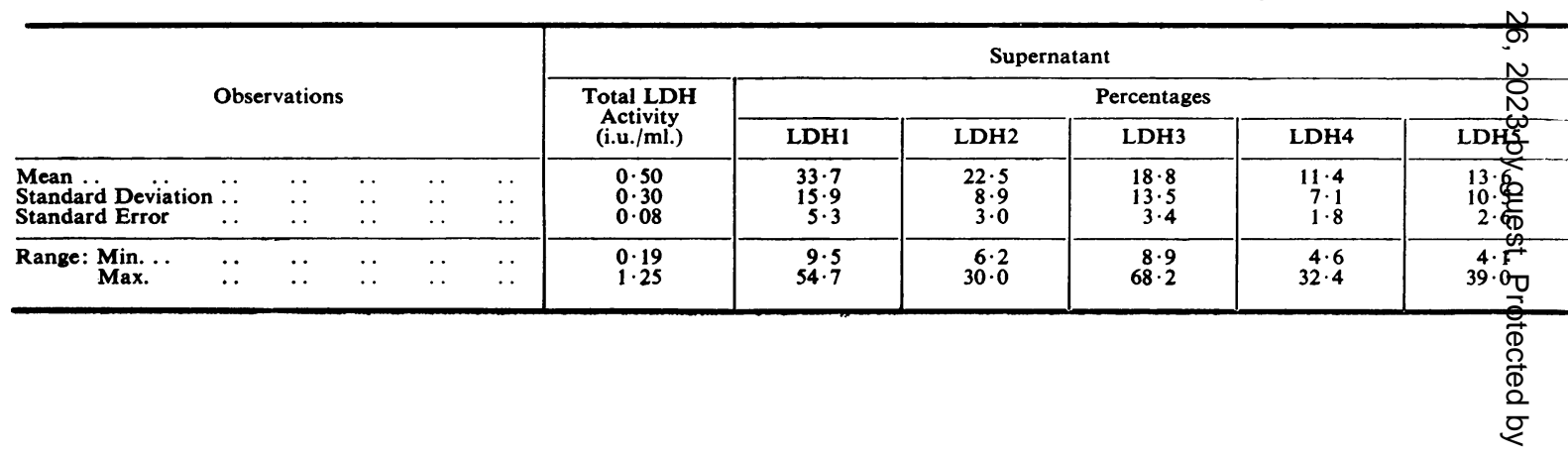


considered only as rough indications. In a log normal distribution, the ranges are more significant and these have been added to the Tables.

\section{(1) Rheumatoid Arthritis (Table II)}

56 synovial fluids from 51 patients were examined; 47 had classical or definite, and four probable rheumatoid arthritis, according to the ARA criteria of Ropes, Bennett, Cobb, Jacox, and Jessar (1959).

In cell-free fluid, the total LDH activity was high ( $>0.50$ i.u. $/ \mathrm{ml}$.) in 49 samples. In seven fluids only a minimal increase was found (between 0.31 and 0.45 i.u./ml.).

In the LDH patterns an increased percentage of isoenzyme LDH5 was found in fifty fluids LDH5 (> 20 per cent.) and one had a marked rise of LDH3 (= 45.5 per cent.). The other five cases had a high combined value of LDH1 + LDH2 (> 50 per cent.), and in these cases the LDH1 and LDH2 were not separated. This absence of separation between
LDH1 and LDH2 was also encountered in sixteen other samples. No obvious technical reason for this phenomenon can be given.

In cellular material the total LDH activity, determined under the standardized conditions described above, was found to exceed the level of 0.50 i.u./ $\mathrm{ml}$. in all but one case, in which the value was yet very close $(0.48$ i.u. $/ \mathrm{ml}$.). The percentage of isoenzyme LDH5 was high ( $>20$ per cent.) in all of them.

All but two cases had raised total white blood cell counts ( $>200 \mathrm{WBC} / \mathrm{cu}$. mm.), and all samples had an increased percentage of polymorphonuclear cells ( $>25$ per cent.).

\section{(2) Juvenile Rheumatoid Arthritis (Table III)}

Table III presents the analysis of six fluids from four patients. All samples had a mildly raised total LDH activity ( $>0.50$ i.u. $/ \mathrm{ml}$.) in cell-free fluid and their isoenzyme patterns showed a shift II

RHEUMATOID ARTHRITIS (56 SAMPLES)

\begin{tabular}{|c|c|c|c|c|c|c|c|c|}
\hline \multicolumn{6}{|c|}{ Cellular Material } & \multicolumn{3}{|c|}{ Cell Counts } \\
\hline \multirow{2}{*}{$\begin{array}{l}\text { Total LDH } \\
\text { Activity } \\
\text { (i.u./ml.) }\end{array}$} & \multicolumn{5}{|c|}{ Percentages } & \multirow{2}{*}{$\begin{array}{c}\text { Total } \\
\text { WBC/cu. mm. }\end{array}$} & \multicolumn{2}{|c|}{ Percentages } \\
\hline & LDH1 & LDH2 & LDH3 & LDH4 & LDH5 & & PMN & Lymphocytes \\
\hline $\begin{array}{l}6 \cdot 24 \\
6.71 \\
0.89\end{array}$ & $\begin{array}{l}6 \cdot 3 \\
5 \cdot 4 \\
0 \cdot 7\end{array}$ & $\begin{array}{r}14 \cdot 2 \\
10 \cdot 1 \\
1 \cdot 4\end{array}$ & $\begin{array}{r}19.9 \\
9.9 \\
1.3\end{array}$ & $\begin{array}{r}24 \cdot 2 \\
4 \cdot 1 \\
0 \cdot 5\end{array}$ & $\begin{array}{r}35 \cdot 2 \\
7.8 \\
1 \cdot 1\end{array}$ & $\begin{array}{r}12,230 \\
11,800 \\
1,600\end{array}$ & $\begin{array}{r}66 \\
17 \\
2\end{array}$ & $\begin{array}{r}34 \\
15 \\
2\end{array}$ \\
\hline $\begin{array}{r}0 \cdot 48 \\
38 \cdot 40\end{array}$ & $\begin{array}{r}0 \cdot 2 \\
24 \cdot 5\end{array}$ & $\begin{array}{r}2 \cdot 8 \\
24 \cdot 0\end{array}$ & $\begin{array}{r}3 \cdot 4 \\
25 \cdot 3\end{array}$ & $\begin{array}{l}16 \cdot 7 \\
34 \cdot 4\end{array}$ & $\begin{array}{l}22 \cdot 5 \\
65 \cdot 4\end{array}$ & $\begin{array}{r}400 \\
76,000\end{array}$ & $\begin{array}{l}22 \\
93\end{array}$ & $\begin{array}{r}7 \\
78\end{array}$ \\
\hline
\end{tabular}

III

JUVENILE RHEUMATOID ARTHRITIS (6 SAMPLES)

\begin{tabular}{|c|c|c|c|c|c|c|c|c|}
\hline \multicolumn{6}{|c|}{ Cellular Material } & \multicolumn{3}{|c|}{ Cell Counts } \\
\hline \multirow{2}{*}{$\begin{array}{l}\text { Total LDH } \\
\text { Activity } \\
\text { (i.u./ml.) }\end{array}$} & \multicolumn{5}{|c|}{ Percentages } & \multirow{2}{*}{$\begin{array}{c}\text { Total } \\
\text { WBC/cu. mm. }\end{array}$} & \multicolumn{2}{|c|}{ Percentages } \\
\hline & LDH1 & LDH2 & LDH3 & LDH4 & LDH5 & & PMN & Lymphocytes \\
\hline $\begin{array}{l}1 \cdot 65 \\
1 \cdot 37 \\
0.57\end{array}$ & $\begin{array}{l}4 \cdot 3 \\
3.9 \\
1.6\end{array}$ & $\begin{array}{r}13 \cdot 5 \\
4 \cdot 5 \\
1.9\end{array}$ & $\begin{array}{r}26 \cdot 6 \\
2 \cdot 7 \\
1 \cdot 1\end{array}$ & $\begin{array}{r}30 \cdot 8 \\
5 \cdot 0 \\
2 \cdot 1\end{array}$ & $\begin{array}{r}24 \cdot 8 \\
5 \cdot 5 \\
2 \cdot 3\end{array}$ & $\begin{array}{r}2,200 \\
1,100 \\
460\end{array}$ & $\begin{array}{r}47 \\
16 \\
7\end{array}$ & $\begin{array}{r}52 \\
17 \\
7\end{array}$ \\
\hline $\begin{array}{l}0.34 \\
3.46\end{array}$ & $10 \overline{7}$ & $\begin{array}{r}7 \cdot 5 \\
19 \cdot 4\end{array}$ & $\begin{array}{l}23 \cdot 5 \\
31 \cdot 5\end{array}$ & $\begin{array}{l}24 \cdot 4 \\
38 \cdot 5\end{array}$ & $\begin{array}{l}16 \cdot 1 \\
29 \cdot 8\end{array}$ & $\begin{array}{r}700 \\
3,300\end{array}$ & $\begin{array}{l}27 \\
64\end{array}$ & $\begin{array}{l}31 \\
73\end{array}$ \\
\hline
\end{tabular}

IV

ARTHRITIS OR TRAUMATIC JOINT EFFUSION (12 SAMPLES)

\begin{tabular}{|c|c|c|c|c|c|c|c|c|}
\hline \multicolumn{6}{|c|}{ Cellular Material } & \multicolumn{3}{|c|}{ Cell Counts } \\
\hline \multirow{2}{*}{$\begin{array}{l}\text { Total LDH } \\
\text { Activity } \\
\text { (i.u./ml.) }\end{array}$} & \multicolumn{5}{|c|}{ Percentages } & \multirow{2}{*}{$\begin{array}{c}\text { Total } \\
\text { WBC/cu. mm. }\end{array}$} & \multicolumn{2}{|c|}{ Percentages } \\
\hline & LDH1 & LDH2 & LDH3 & LDH4 & LDH5 & & PMN & Lymphocytes \\
\hline $\begin{array}{l}0 \cdot 35 \\
0 \cdot 28 \\
0 \cdot 08\end{array}$ & $\begin{array}{l}5 \cdot 2 \\
4 \cdot 3 \\
1 \cdot 3\end{array}$ & $\begin{array}{r}11 \cdot 6 \\
5 \cdot 1 \\
1 \cdot 5\end{array}$ & $\begin{array}{r}19 \cdot 6 \\
10 \cdot 7 \\
3 \cdot 0\end{array}$ & $\begin{array}{r}27 \cdot 1 \\
9 \cdot 5 \\
2 \cdot 7\end{array}$ & $\begin{array}{r}28 \cdot 3 \\
14 \cdot 9 \\
4 \cdot 2\end{array}$ & $\begin{array}{r}1,850 \\
2,680 \\
720\end{array}$ & $\begin{array}{r}20 \\
12 \\
4\end{array}$ & $\begin{array}{r}76 \\
11 \\
4\end{array}$ \\
\hline $\begin{array}{l}0.07 \\
1.01\end{array}$ & $\begin{array}{r}3 \cdot 1 \\
13 \cdot 6\end{array}$ & $\begin{array}{r}8 \cdot 4 \\
20 \cdot 0\end{array}$ & $\begin{array}{r}5 \cdot 4 \\
33 \cdot 2\end{array}$ & $\begin{array}{r}2 \cdot 9 \\
36 \cdot 2\end{array}$ & $\begin{array}{r}4 \cdot 0 \\
62 \cdot 3\end{array}$ & $\begin{array}{r}100 \\
10,000\end{array}$ & $\begin{array}{r}5 \\
36\end{array}$ & $\begin{array}{l}64 \\
95\end{array}$ \\
\hline
\end{tabular}


towards an increase of LDH2 ( $>20$ per cent.) and of LDH3 (> 20 per cent.). Two samples were found to have in addition a rise in LDH5 percentage (25 and 21 per cent.). On the cellular material, LDH activity was high ( $>0.50$ i.u. $/ \mathrm{ml}$.) in four cases and the percentage of LDH5 was raised in five fluids ( $>20$ per cent.).

The total WBC and PMN were raised in all samples.

(3) Degenerative Arthritis and Traumatic Effusions (Table IV, previous pp. 570 and 571)

Twelve samples were analysed, four from patients with degenerative arthritis and eight from patients with traumatic effusion of the knee. The results are summarized in Table IV. In cell-free fluid the total LDH activity was low in eleven samples $(<0.50$ i.u./ml.). In all but three samples the percentage of LDH5 was low ( $<20$ per cent.).

In cellular material, the total LDH activity was low ( $<0.50$ i.u./ml.) in all but one in which a slight increase of LDH activity was found. A high percentage of LDH3 ( $>30$ per cent.) and LDH4 ( $>30$ per cent.) was found in cases of degenerative arthritis, whereas in traumatic effusion the percentage of LDH4 and LDH5 was raised ( $>20$ per cent.).

All the fluids demonstrated a moderate increase in the white blood cell counts (mean: 1,850 cells/ cu. mm.).

\section{(4) Gout and Ankylosing Spondylitis (Table V)}

Two cases of gouty arthritis and one of ankylosing spondylitis with peripheral joint involvement were analysed. The two cases of gouty arthritis had low LDH activity in cell-free fluid and in cellular material ( $<0.50$ i.u. $/ \mathrm{ml}$.) and the WBC count was normal. Only the cellular material of the patient with ankylosing spondylitis could be analysed, and this showed a mild rise in LDH activity $(=0.80$ i.u./ml.), a low percentage of LDH5 (= 6 per cent.), and a raised WBC count $(=2,000$ cells/cu. mm.).

\section{(5) Infectious Arthritis (Table V)}

Only two cases of infectious arthritis could be analysed (one case of tuberculosis of the knee, and one in which a haemolytic Staphylococcus aureus was cultured from the joint fluid).

In both cases LDH activity was markedly increased in cell-free fluid ( $>4 \mathrm{i} . \mathrm{u} . / \mathrm{ml}$.) and in cellular material ( $>20$ i.u./ml.). The percentage of isoenzyme LDH5 was high in the cell-free fluid ( $>28$ per cent.) as well as in the cell extract ( $>28$ per cent.). The WBC counts and PMN percentages were also increased.

\section{(6) Effusions with Ill-defined Aetiology}

The effusions of seven cases of so-called chronic synovitis were examined. Two had the anatomopathological appearance of rheumatoid arthritis, but did not display enough clinical, radiological, and biological data to establish this diagnosis. In this group the results differed from case to case, and the calculation of mean values has no practical interest.

\section{Discussion}

Considering the small amounts of synovial fluid available in normal joints, it is difficult to determine the total LDH activity and the LDH isoenzyme pattern of normal material; we are restricted to a comparison of different kinds of pathological fluids, and our use of such terms as "raised" or "decreased" is to be interpreted in this way.

In seeking a possible correlation between total LDH activity of the cellular material and the total WBC count, we obtained a linear correlation only by choosing a $\log / \log$ plot (Fig. 1). Although this observation suggests the intervention of rate processes, we will not venture here into any hypothesis. We merely call attention to the fact that the frequency distribution curves for total LDH in the cell-free material and in the cellular extracts, as well as the cell counts themselves, are of the lognormal type (Fig. 2).

MEAN FINDINGS IN SYNOVIAL FLUIDS OF THREE PATIENTS WITH GOUT OR PATIENTS WITH ANKYLOS

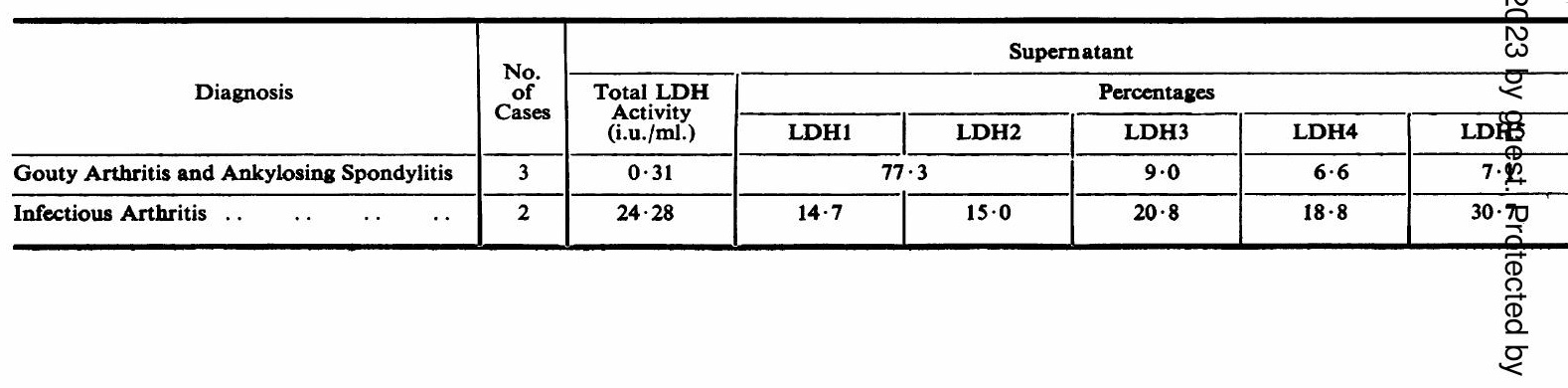




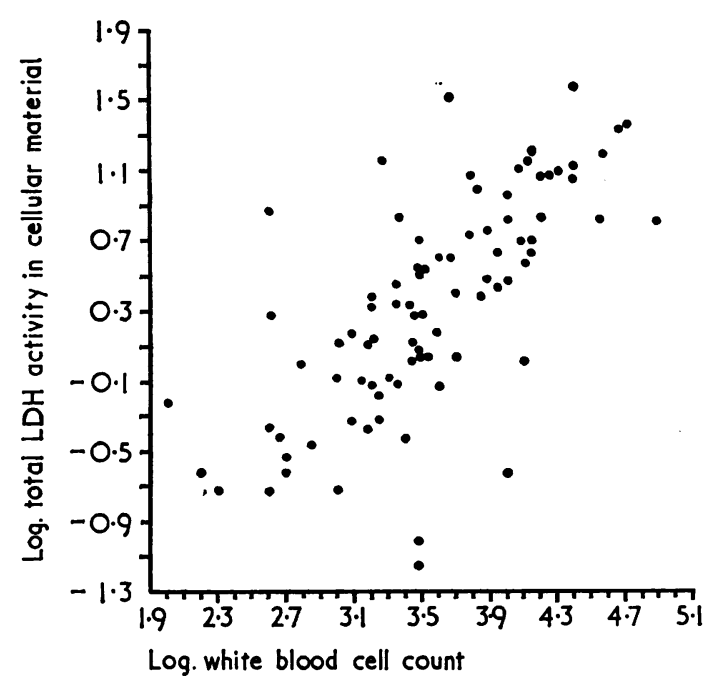

Fig. 1.-Log./log. plot of total LDH activity in cellular material and WBC count.

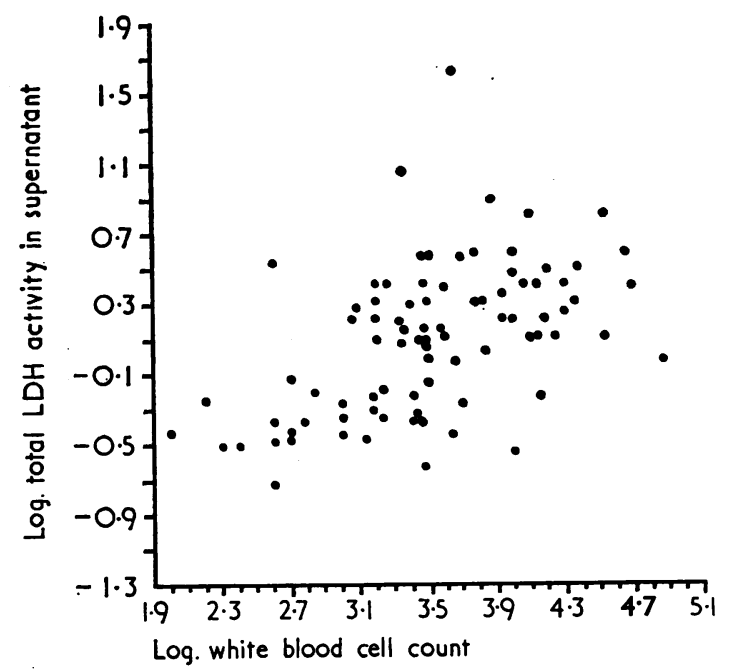

Fig. 3.-Log./log. plot of total LDH activity in supernatant and WBC count.

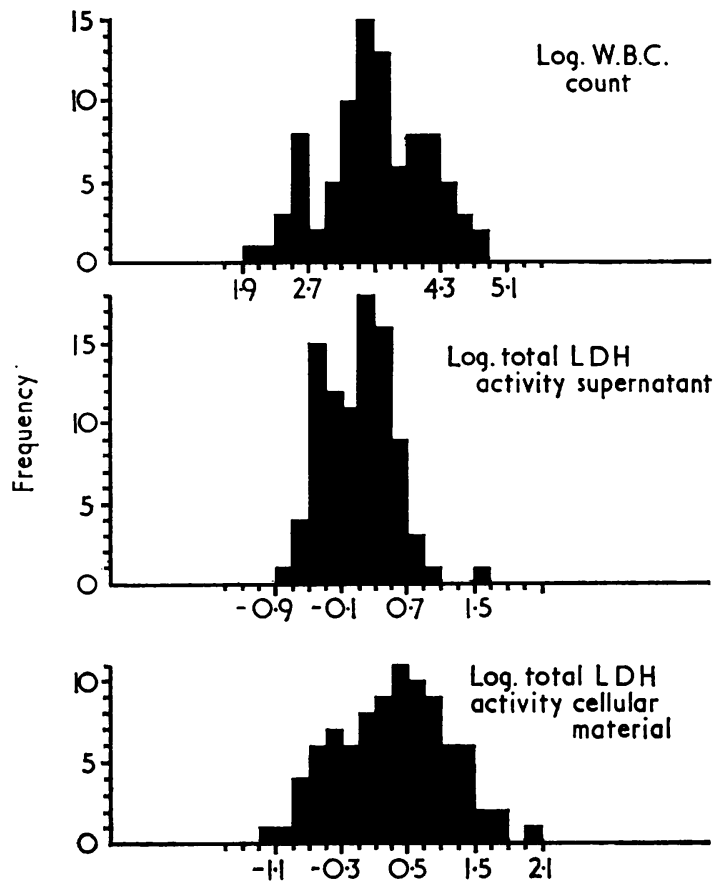

Fig. 2.-Frequency distribution of the logarithms of WBC counts and of the total LDH activity in cell free supernatant and in cellular material.

In the cell-free supernatant the total LDH concentration does not correlate well with the cell counts even after a $\log / \log$ transformation (Fig. 3). Nor does its LDH pattern seem to be determined exclusively by the leucocyte contents of the fluid. West, Poske, Black, Pilz, and Zimmerman (1963) suggested that an increase in LDH activity in synovial fluid might result from release of enzymes from leucocytes, or from necrotic or inflamed synovial tissue. In fact, we did not find a marked correlation between the number of leucocytes in the biopsy samples and the total LDH levels of the corresponding cell-free fluids. The synovial lining cells are reported to be rich in LDH (Hamerman and Blum, 1959), but very little is known about their LDH patterns. In a preliminary investigation we have

NDYLITIS WITH PERIPHERAL INVOLVEMENT, AND OF TWO PATIENTS WITH INFECTIOUS ARTHRITIS

\begin{tabular}{|c|c|c|c|c|c|c|c|c|}
\hline (i.u./ml.) & LDH1 & LDH2 & LDH3 & LDH4 & LDH5 & WBC/cu. mm. & PMN & Lymphocytes \\
\hline $27 \cdot 25$ & $7 \cdot 0$ & $21 \cdot 0$ & $22 \cdot 9$ & $19 \cdot 5$ & $29 \cdot 4$ & 25,000 & 87 & 13 \\
\hline
\end{tabular}


found that the LDH5 fraction markedly predominates in normal synovial tissue.

Many fluids have the same LDH pattern for the cellular extract as for the cell-free supernatant, but exceptions to this rule are not infrequent. Fluids with low total LDH activity in cell-free supernatant generally have a low percentage of LDH5, but the cellular material of such fluids frequently exhibits a high LDH5 percentage (traumatic effusions).

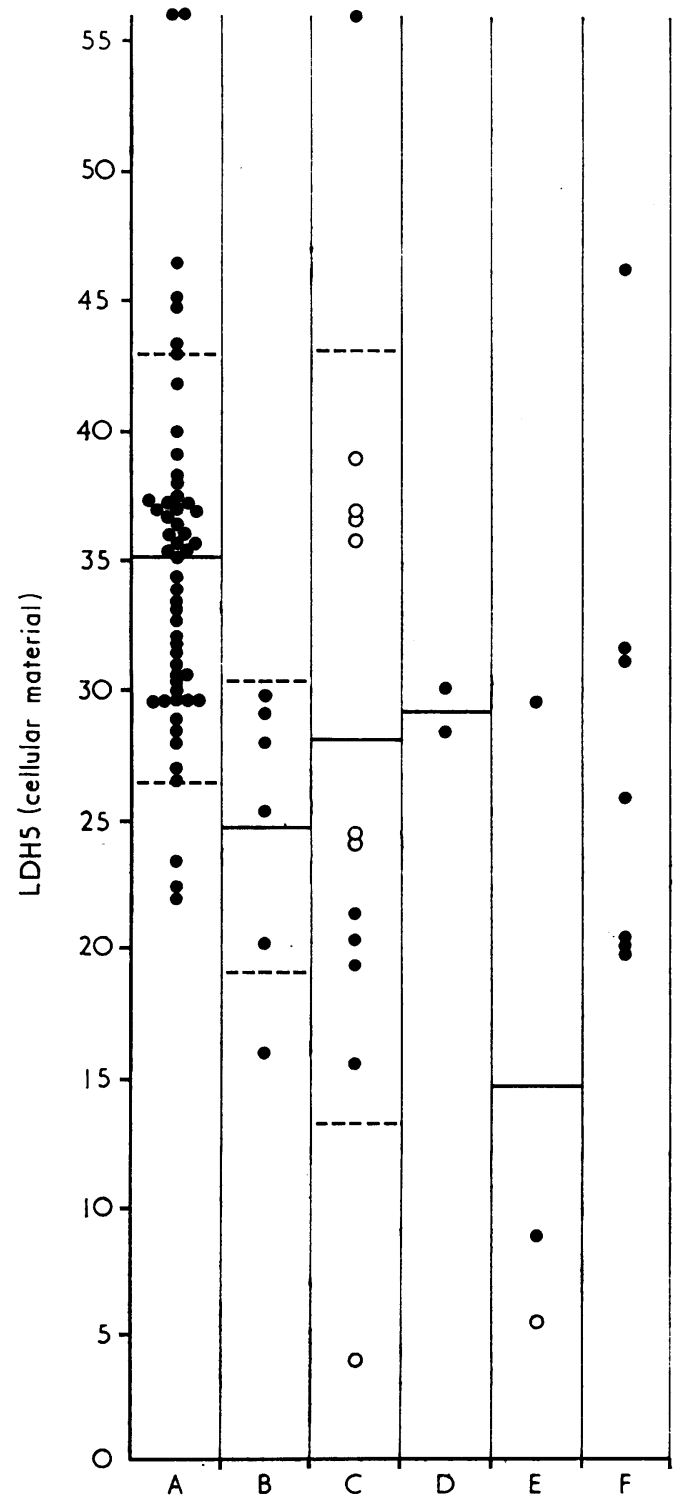

Fig. 4.-Percentages of LDH5 isoenzyme in cellular material from symovial fluids in different rheumatic conditions. Limits defined by $2 \mathrm{~s}$ indicated by broken lines where relevant.
Considering the LDH patterns obtained in effusions of different aetiology, one finds in the first place the increase of LDH5 percentage in cellular extracts and also in the cell-free fluid, which is encountered in practically all cases of rheumatoid arthritis. However, the same shift was encountered in effusions of very different aetiology (Fig. 4).

By itself this shift thus seems of little diagnostic value, but if one determines total LDH5 activity of the cellular material, interesting data appear (Fig. 5).

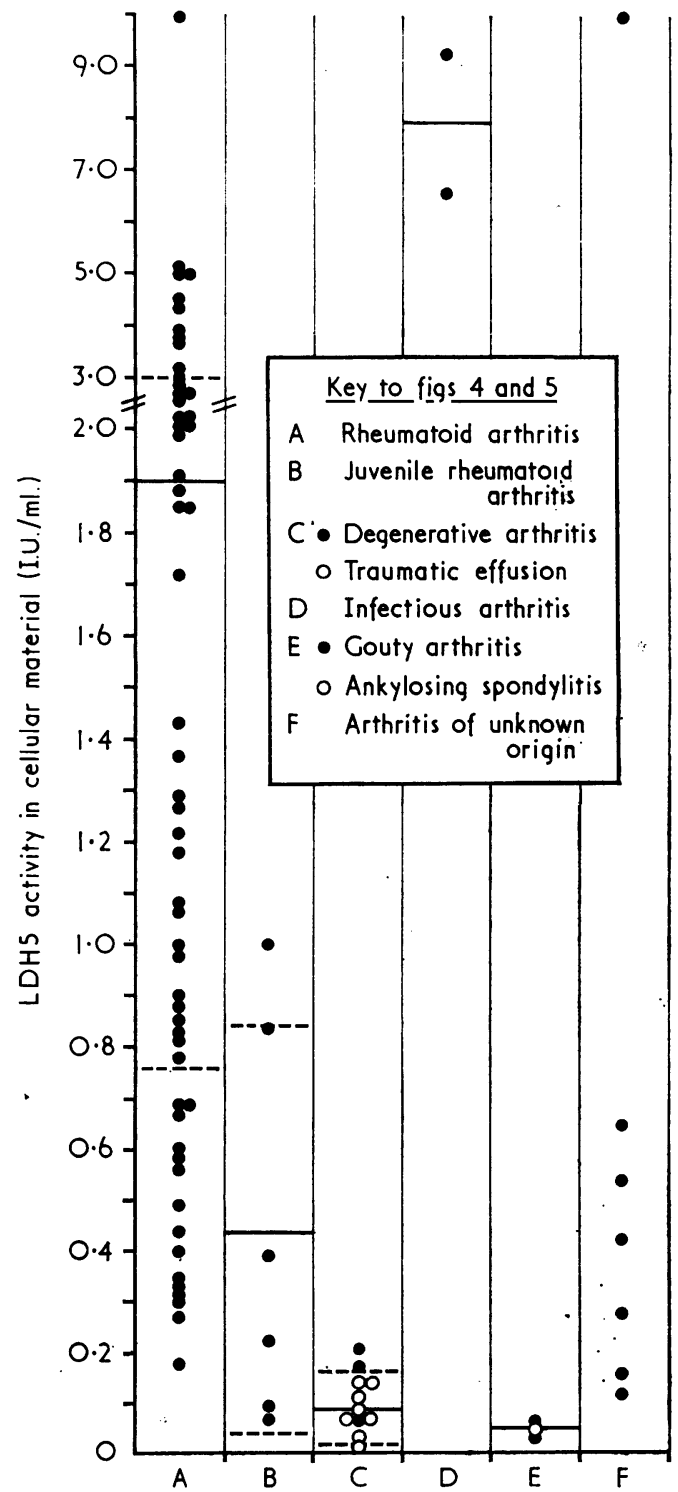

Fig. 5.-Total LDH5 isoenzyme activity in cellular material from synovial fluids in different rheumatic conditions. Limits defined by $2 \mathrm{~s}$ indicated by broken lines where relevant. 
Cases of infectious arthritis then clearly emerge with the highest values for LDH5 activity in cellular material, and next come the cases of rheumatoid arthritis. Total LDH5 activity is low in traumatic effusions, degenerative arthritis, gouty arthritis, and ankylosing spondylitis. Four fluids from two cases of juvenile rheumatoid arthritis had LDH5 activities comparable with those of adult rheumatoid arthritis. Of 56 patients with rheumatoid arthritis, only three had low total LDH5 activity in cellular material. Two of these three were patients with very low disease activity and a low erythrocyte sedimentation rate but extensive articular destruction, apparently two burned-out cases. We have no explanation for the third case.

In the limited group of cases of ill-defined aetiology we found divergent values for LDH5 activity in cellular material. This is, of course, to be expected and will not be further commented upon.

Our main conclusion is that it is more important to determine the LDH activity in the cellular material of synovial fluids than in the cell-free supernatant. In contradistinction to other joint diseases, excluding cases of infectious arthritis where total LDH5 is extremely high, cases of rheumatoid arthritis are characterized by high values of total LDH5 activity in cellular extracts when this is determined by the procedure here described, which composes an integration of the qualitative and quantitative modifications of the cellular material.

The technique is easy and rapid, but one should give due care to the details mentioned in our description of the procedure. Under these conditions the analysis seems to yield interesting diagnostic information.

\section{Summary}

The LDH contents and isoenzyme patterns have been studied in cell-free synovial fluid and in cellular material after ultrasonic disintegration. The total LDH activity was measured by a spectrophotometric technique using the pyruvate to lactate conversion. The LDH isoenzyme patterns were established by agar gel electrophoresis followed by a tetrazolium enzymatic staining reaction.

86 synovial fluids were analysed in 56 cases of rheumatoid arthritis, six cases of juvenile rheumatoid arthritis, twelve of traumatic effusion and degenerative arthritis, two cases of infectious arthritis, two of gouty arthritis, one of ankylosing spondylitis, and seven of synovitis of ill-defined aetiology.

The cases of rheumatoid arthritis had high total LDH activity both in cell-free fluid and in cellular material. These cases had also an increased percentage of LDH5 in the cellular extract. A similar shift was encountered in effusions of very different aetiology. By combining the two types of results interesting data appear. When the total LDH5 concentration in the cellular extracts is calculated, cases of infectious arthritis clearly emerge with the highest value for LDH5 activity ( $>8 \mathrm{i} . \mathrm{u} . / \mathrm{ml}$. under specified conditions), and next come the cases of rheumatoid arthritis ( $>1.9$ i.u./ml.). The total LDH5 activity remains low in traumatic effusions and also in fluids from cases of degenerative arthritis, gouty arthritis, and ankylosing spondylitis.

It is concluded that the combined analysis of total LDH and of the LDH isoenzyme patterns constitutes a useful diagnostic aid when applied to the cellular material present in effusions.

\section{REFERENCES}

Bottomley, R. H., Locke, S. J., and Ingram, H. C. (1966). Blood, 27, 85 (Lactic dehydrogenase of human chronic lymphocytic leukemic leukocytes).

Cohen, A. S. (1964). Arthr. and Rheum., 7, 490 (Lactic dehydrogenase (LDH) and transaminase (GOT) activity of synovial fluid and serum in rheumatic disease states, with a note on synovial fluid LDH isozymes).

Dioguardi, N., Agostoni, A., Fiorelli, G., and Lomanto, B. (1963). J. Lab. clin. Med., 61, 713 (Characterization of lactic dehydrogenase of normal human granulocytes).

Hamerman, D., and Blum, M. (1959). Arthr. and Rheum., 2, 553 (Histologic studies on human synovial membrane. 2.).

Helm, H. J. van der (1961). Lancet, Letter to the Editor, 2, 108 (Simple method of demonstrating lactic acid dehydrogenase isoenzymes).

Hule, V. (1967). Clin. chim. Acta, 17, 349 (Lactate dehydrogenase isoenzyme patterns of human lymphatic and myeloid leukemic leukocytes).

Jessar, R. A. (1966). In "Arthritis and Allied Conditions", 7th ed., ed. J. L. Hollander, p. 70 (The synovial fluid). Febiger, Philadelphia.

Ropes, M. W., and Bauer, W. (1953). "Synovial Fluid Changes in Joint Disease". Harvard University Press, Cambridge, Massachusetts.

_ _ Bennett, G. A., Cobb, S., Jacox, R., and Jessar, R. A. (1959). Ann. rheum. Dis., 18, 49 (1958 Diagnostic criteria for rheumatoid arthritis). 
Vesell, E. S., Osterland, K. C., Bearn, A. G., and Kunkel, H. G. (1962). J. clin. Invest., 41, 2012 (Isozymes of lactic dehydrogenase; their alterations in arthritic synovial fluid and sera).

West, M., Poske, R. M., Black, A. B., Pilz, C. G., and Zimmerman, H. J. (1963). J. Lab. clin. Med., 62, 175 (Enzyme activity in synovial fluid).

Wieme, R. J. (1959). Clin. chim. Acta, 4, 317 (An improved technique of agar-gel electrophoresis on microscope slides).

- (1965). "Agar Gel Electrophoresis". Elsevier, Amsterdam.

- Sande, M. van, Karcher, D., Lowenthal, A., and Helm, M. J. van der (1962). Clin. chim. Acta, 7, 750 (A modified technique for direct staining with nitro-blue tetrazolium of lactate dehydrogenase iso-enzymes upon agar gel electrophoresis).

La lacticodéshydrogénase (LDH) dans le liquide synovial. Evaluation diagnostique de l'activité totale et du tableau des isoenzymes

\section{RÉSUMÉ}

On étudia la LDH et le tableau de ses isoenzymes dans le liquide synovial sans eléments figurés et dans son contenu cellulaire après désintégration ultrasonique. L'activité totale de la LDH fut mesurée par la méthode spectrophotométrique en usant la conversion du pyruvate au lactate. Le tableau des isoenzymes fut déterminé par l'électrophorèse sur gélose suivie de la réaction de coloration enzymatique au tetrazolium.

On fit l'analyse de 86 liquides synoviaux provenant de 56 cas de polyarthrite rhumatoïde, six cas de polyarthrite rhumatoïde juvénile, douze cas d'hydarthrose traumatique et d'arthrite dégénérative, deux cas d'arthrite infectieuse, deux cas d'arthrite goutteuse, deux cas de spondylarthrite ankylosante et sept cas de synovite d'origine mal connue.

Les cas de polyarthrite rhumatoïde accusèrent une forte activité totale de la LDH tant dans le liquide synovial purifié que dans le matériel cellulaire séparé. Le pourcentage de la fraction LDH5 fut aussi augmenté dans ce matériel. On trouva une déviation similaire dans des épanchements étiologiquement très différents. Lorsqu'on rapproche ces deux types des résultats, on obtient des données intéressantes: l'activité totale de la LDH5 du matériel cellulaire est la plus forte $(>8 \mathrm{u} . \mathrm{i} . / \mathrm{ml}$. en conditions spécifiques) dans l'arthrite infectieuse; la polyarthrite rhumatoïde prend la deuxième place $(>1,9$ u.i./ml.) et elle est toujours basse dans les épanchement traumatiques et dans les liquides synoviaux des cas d'arthrite dégénérative, goutteuse et de spondylarthrite ankylosante.

On conclut que l'analyse combinée de la LDH totale et du ses isoenzymes est une aide diagnostique utile lorsqu'on l'applique au matériel cellulaire présent dans les épanchements.
La lacticodeshidrogenasa (LDH) en el líquido sinovial. Valoración diagnóstica de la actividad total y del cuadro de las isoenzimas

\section{SUMARIO}

Se estudió la LDH y el cuadro de sus isoenzimas en el líquido sinovial sin elementos figurados y en su contenido celular separado, después de desintegración ultrasónica. La actividad total de la LDH fué medida por el método espectrofotométrico empleando la conversión del piruvato al lactato. El cuadro de las isoenzimas fué determinado por electroforesis sobre gelosa, seguida de la reacción de coloración enzimática con tetrazolium.

Se analizaron 86 líquidos sinoviales de 56 casos de poliartritis reumatoide, seis de artritis reumatoide juvenil, doce de hidartrosis traumática y de artritis degenerativa, dos de artritis infecciosa, dos de artritis gotosa, dos de espondilartritis anquilosante y siete casos de sinovitis de etiología mal definida.

Los casos de poliartritis reumatoide acusaron una fuerte actividad total de la $\mathrm{LDH}$ tanto en el líquido sinovial sin elementos figurados como en el extracto celular. En este extracto la fracción LDH5 fué también aumentada. Una deviación similar fué encontrada en derrames etiológicamente muy diferentes. Ambos tipos de resultados considerados conjuntamente ofrecen datos interesantes: la actividad total de la LDH5 del material celular es la más fuerte $(>8 \mathrm{u}$.i./ $/ \mathrm{ml}$. en condiciones específicas) en la artritis infecciosa; en segundo lugar va la poliartritis reumatoide $(>1,9$ u.i. $/ \mathrm{ml}$.). La actividad total de la LDH5 queda baja en derrames traumáticos y en líquidos sinoviales de los casos de artritis degenerativa, gotosa y de espondilartritis anquilosante.

Se concluye que el análisis combinado de la LDH total y del cuadro de sus isoenzimas es de gran utilidad diagnóstica en su aplicación al material celular presente en derrames. 